\title{
NATIONAL RESILIENCE STRENGTHEN THROUGH THE RESERVE COMPONENT TO RESIST NON-MILITARY THREATS
}

\author{
Agape Zacharia $\mathrm{RD}^{1}{ }^{凶}$, Faisal Ahmadani ${ }^{2}$ and Patria Danianto ${ }^{3}$ \\ ${ }^{1}$ Defense Strategy Faculty, Indonesia, Defense University, Indonesia \\ ${ }^{2}$ School of Strategic and Global Studies, University of Indonesia, Indonesia \\ ${ }^{3}$ National Resilience Study Postgraduate Program, Gadjah Mada University, Indonesia
}
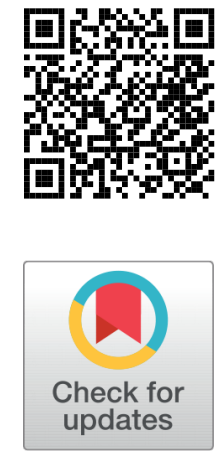

Received 6 May 2021

Accepted 20 May 2021

Published 31 May 2021

Corresponding Author

Agape Zacharia RD, agazd@ymail. com

DOI $10.29121 /$

granthaalayah.v9.i5.2021.3965

Funding: This research received no specific grant from any funding agency in the public, commercial, or not-for-profit sectors.

Copyright: (C) 2021 The Author(s). This is an open access article distributed under the terms of the Creative Commons Attribution License, which permits unrestricted use, distribution, and reproduction in any medium, provided the original author and source are credited.

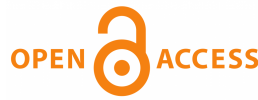

\section{ABSTRACT}

National Resilience is a nation dynamic condition, and a nation struggle to achieve national goal will be disturbed. National identity, national integration and national life sustainability have stronger than threat, challenge, disturbance and obstacle. This research uses qualitative research method to analyze potential threat, challenge, disturbing and obstacle for Indonesia, which come both from internal and external sources and national resources to face them. In future, potential threat will be dominated by nonmilitary threat. The Indonesia Armed Forces (Tentara Nasional Indonesia), as the main component in Indonesia should face the potential threat. But TNI has its limitations, supporting power is necessary, and one of the potential powers is national resources which or whom converted to reserve component. The role of reserve component in future will contribute to Indonesia national resilience strengthen efforts.

Keywords: National, Resilience, Strengthen, Reserve, Component

\section{INTRODUCTION}

As other country in the world, Indonesia face with threat, challenge, disturbance and obstacle and need to strengthen national resilience. The threat especially is being changed, transforming or converting from military threat or conventional threat to nonmilitary threat or unconventional threat. As the result, major threat come from internal sources and the external threat come rarely. Unconventional threat such as: transnational crime, human trafficking, narcotics, corruption, terrorism, and other unconventional threats are emerging nowadays and in future.

To fight against the threat, military power is not the one power to fight with, because of its natural characteristic. The threat is moving toward not only the nation, but moving forward to individual or personal threat. The people are becoming pragmatist, they never care about the national interest. The threat is intangible, a condition looks like the condition during Cold War, when ideological offense attacked, but 
the threat spreading is wider or broader, not only the nation but more than it, each citizen. Different approach is necessary. The problems which faced by Indonesian Armed Forces (Tentara Nasional Indonesia or TNI) and Indonesian National Police (Kepolisian Negara Republik Indonesia or Polri) are complex, and both national institutions have their own limitations. One of the ways to solve this problem is establish national reserve component, to strengthen TNI as the main component specially to fight or to face with nonmilitary threat.

Reserve component is state defense implementation with Pancasila paradigm. Pancasila as Indonesian ideology is a fundamental value to develop national resilience and the basic need to the reservist as a basic knowledge, which delivered or transform to them, to build personal awareness with state defense spirit and nationalism and patriotism as two other basic spirits. State defense with Pancasila paradigm is transferred to the reservist to build their capacity in fight with nonmilitary threat. Individual contribution in national defense system is a compulsory for all citizen. That's mean state defense is individual responsibility based on Law No. $3 / 2002$. One of reason to form reserve component is the contingency when face both conventional and unconventional threat.

This research uses qualitative method, with descriptive analysis to gain the aim of the research. The aim of this research is to analysis and conclude empirical data within literature review which describe the need to form or establish reserve component in Indonesia defense system in order to contribute in Indonesia national resilience development.

\section{RESULTS AND DISCUSSIONS}

National Resilience is about national capacity and capability to face with threat, challenge, disturbance and obstacle. National Resilience discuses about strength and tenacity as dynamic situation. It also discusses about how a nation face direct and indirect threat, which emerging from internal and external sources. National resilience also guarding a national strategy to achieve national goal while facing threat which threaten national identity, national integration, national struggle and national life sustainability, accordance to the word order in recent days. National resilience must be developed and arranged to face the change of world order, to face with globalization and borderless relation in global relationship. National resilience could be understood deeper or wider, both individual or social perspective to construct a detail and wider understanding about Indonesia national resilience based on Indonesia diversity which consist of several tribes, religions, race, and culture within an archipelago Bambang and Pranowo (2010). Basically, in this context, national resilience is a message that every element has to cooperate with other national element refer to each element's responsibility, not only Minister of

Defense nor TNI. Every national element has similar and equal responsibility to develop national resilience. Why? Because national resilience impacted all national 
life aspects, including: economy, socio culture, politics, religion and much more. There is single institution or ego sectoral implementation. No reason to resist that national resilience is collective interest. Individualism perspective in national life will decrease the quality of national life and that is mean, a decrease of national dynamic condition. Defense and security are not the only one aspect of national resilience, but without national security, it is impossible for other aspect to develop a single aspect resilience.

In order to the total defense system (Sistem Pertahanan Semesta or Sishanta), the reserve component may also involve in Military Operation Other than War (MOOW). From this perspective, the total war is defined by involving civilian (non-military) elements to engage in military humanitarian aid, and called as reserve component. That is the reason why the reserve components can be formed as an element of non-military state defense to strengthen the main component Indrawan and Efriza (2018). The reservists are not professional soldier, the people who selected and trained hard to fight against their enemy in the middle of battlefield. The reservist engagement in MOOW is a possibility today. The fact now, is TNI has a little probability to fight with the belligerent in a war, face an aggression or an invasion. The possible role or task for TNI now and future is MOOW mission, supporting Polri to fight against terrorism or separatism. But it is right, one of the main tasks for TNI is humanitarian assistance or aid, because Indonesia is one of the countries in the world with high natural disaster risk. For this reason, the reserve component deployment probability is to support TNI as the main component conducting a humanitarian operation natural disaster area, not to fight with terrorism or separatism. Fragmentation in the middle of public area occurred and caused by negative mass communication through social media, and state defense awareness in cyber space must be actualized. The citizens who take a part in the reserve component could projected as state defense awareness agents, who spreading positive messages through social media. For example, the resistance to confront radicalism spreading in social media space. The reservist as the agent of state defense awareness run the role to prevent radicalism messages spreading.

According to Law No. 3/2002, citizen's role as reserve component and supporting component in the defense of the state in facing both military and nonmilitary threats, with the stipulation of provisions on state defense and threats against the increasingly complex Indonesian nation (Bungan and Tukan, 2018, p. 183). The threat paradigm changes every time. There is no guarantee that military threat will come as single threat or nonmilitary threat will come without military power, and we called for this as hybrid threat. The threat complexity is increasing, and the national defense system must be prepared to face with not only military threat but also nonmilitary and hybrid threat. One of an effort to fulfil stipulation of provisions in citizen participation in defense is Law No. 23/2019. In this law, reserve component and supporting component arrange to involve in defense efforts. However, civilian's engagement is defense effort determined by policy makers and decision makers with 
many advices from many parties. The civilians are not to face with military threat. The purpose of national reservist in the middle of community also as the pioneer, the agent of change. The reservist will get a better understanding about national defense, and how the threats targeting all objects or aspects in national life. Reserve component is prepared to nonmilitary threats and nonphysical threats. The complexity of threat is affecting, both physical and nonphysical aspects in national life.

National power is a concept which guided to all aspect in national life, in comprehensive, holistic and integrated way based on Pancasila, The Republic of Indonesia Constitution in 1945 (Undang-Undang Dasar 1945 or UUD 1945) and archipelago insight (wawasan nusantara) through an ideal and harmony implementation between welfare approach and security approach. This concept also a direction to increase effort and tenacity in both welfare and security approach. Describing, welfare as national capability which building national values and security is an effort to keep nationalism value while facing a threat, both from internal and external sources. Politics aspect from national resilience is explained as a conductive condition while facing direct or indirect threat based on Pancasila and UUD 1945 Bambang and Pranowo (2010). This concept understood as a concept how welfare and security holding together, simultaneous and synergy. Based on Indonesia history proved, Pancasila, wawasan nusantara dan UUD 1945 are the main and basic powers and a guarantee for national life. The ideology, the insight and the constitution are the fundamental need in Indonesian national live. Indonesia's diversity (kebhinekaan) is a fact, and coloring Indonesian's identity. Without a concept of national insight, Indonesian will be confused about their national identity, the guarantee to continue "The Founding Fathers" struggle. The condition is different. The founding fathers did their struggle faced with foreign enemy, during the World War and with a lot limitations, without proportional resources, but they did it as the best way of them. Recent days, Indonesia has no foreign enemy, no war and no armed conflict with neighbor country or other country from other region. National resilience today is prepared and developed to face different kind of threat, focus not only on threat but also on obstacle, challenge and disturbance. Although it clear, threat is the most dangerous for national life and the peak of an escalation on obstacle, challenge and disturbance. The threat is conceptual, as a result from uncontrolled obstacle, disturbance or challenge.

With regard to the contemporary and future dynamics of threat, the government is expected to possess legal foundation that can mitigate national security-related threats Mardhani et al. (2020). National security mitigation exactly a part of national resilience measurement. National security strategy proposes the grand strategy to secure national interest. It is mean that if national interest trapped in insecure situation or condition, national resilience going down to middle or high-risk level. The threat mitigation is necessary, from the low level, moderate to high or very high risk, both military and nonmilitary threats. The threat spectrum is broader, complexity characteristic and the way to mitigate more difficult, especially nonmilitary threats. 
Nonmilitary threats are formed in many kinds, come from many sources and press the state to do appropriate strategy to face, to hold and to manage them. Nonmilitary threats should take a cross sectoral strategy, involving many national institutions, and of course, one of the needs is citizen participation. One of the initial ways to ask citizen is reserve component. When citizen become reservist, the citizen has a selfresilience and take a part in national resilience construction. National resilience with Pancasila paradigm as an essential matter for reservist, building an adversity quotient (AQ), another personal quotient beside Intelligence Quotient (IQ), Emotional Quotient (EQ) and Spiritual Quotient (SQ).

National resilience is supporting the government task and role running successfully, for example: in law enforcement and public order to create prosperity, independency in national security management, social justice establishment and the struggle to achieve national goal. This support also gives a chance to people to participate in struggle to keep national life Endang and Sukaya (2000), and so on explaining as below:

1. Tenacity, a power to survive. This tenacity also started from personal level as self-resilience to community resilience and later constructing national resilience.

2. Perseverance, a spirit to achieve national goal hardly. National interest is a grand strategy to gain or achieve national goal. Without national security, it is possible for a nation to reach their national goal. The spirit is a collective spirit, belong to all citizens and accumulating as a national awareness.

3. Identity, a limitation of a community or people organization within region with people, history, government, national goal and national role in international relationship. National identity and personal identity are showing up not only in national level but also in regional and international level.

4. Integrity, the entire aspect of national life, both natural aspect and social aspect, potential and functional characteristic. Integrity is directed toward personal capability, capacity and other potential matter. Integrity shows leadership quality, especially national leaders. National leader and their leadership contribute to national resilience level. Leaders as decision makers and their own integrity influencing national strategy to achieve national goal, at least for short and middle term.

5. Threat, a conceptual effort, criminal and political characteristic and reforming policy and the effort to run the policy. Threat is dangerous matter, with the risk which destructing national life. .

6. Obstacle and disturbance, an effort to reduce or obstacle, not conceptual and come from outside and inside of ourselves. Both, will transform become threat when a particular party or several parties manipulate them gradually and reach the peak escalation while national resources failed to prevent.

National resilience developed as below: 
1. Ideology resilience. A nation condition regarding national soul which directed to a belief in Pancasila as an ideology. A right capability to develop nationalism and national unity and to refuse other ideology which opposite with national personality. Pancasila is an instrument to unity, refer to Indonesia diversity. Pancasila also a national identity, to show that Indonesian are different nation from others.

2. Politic resilience. Democracy life condition based on Pancasila and constitution with a strong intention to keep politics stability and a freedom and active foreign diplomacy or politics. Democracy is one of the important issue post Indonesia reformation in 1998. Politic resilience is indicated by democracy capacity building in Indonesia. The main issue is how the election conducting fairly. Another issue is citizen participation in local and national election. The election institution role in the reformation era not only to conduct the election or to determine electoral threshold but also to conduct a massive public education. Educating public will affect the politic resilience in Indonesia. Law enforcement in political crime also contributes in politic resilience. The fair law enforcement will drive national politic life toward an accountable and transparent elections.

3. Economy resilience. A capability to apply dynamic and stable economy, to realize economy independency with competitiveness. In the free market era, competitiveness is the most important principle. Other issue is protection, a way to protect national products at least in domestic market. Economy independency depend on national capacity to promote national products. Depending in imported product and foreign loan will decrease national capacity to develop national economy resilience. Political will is necessary. A strong political will to develop national economy independency resulted a strong domestic market and monetary stability.

4. Socio culture resilience. Capability to form and develop socio culture life, have faith and imbued by national personality. Foreign culture which adapted by Indonesian could be influenced in two ways: positive war or negative way. It is important to promote, especially among the young to keep national culture and proud as Indonesian. Socio culture resilience is indicated by the effort to refuse negative influence from foreign culture. Socio culture resilience also determined by basic need public services, such as: education and health service.

5. Defense and security resilience. National deterrent condition based on state defense awareness, to maintain national security stability. National security issue is the threats. Multidimensional impact will appear as the impact of globalization. Conflict of interest between national parties and foreign parties are happened. State actors or non-state actors play their role to destruct the whole of national live aspects. Armed approach not the only one approach, diplomacy, law enforcement and humanism approach take the role to maintain national 
security stability. As a learned lesson, the incidents or accidents in the past day should be mitigated with cyclic forecasting or causal forecasting to forecast or measure potential threats. The mitigation will determine the priority, prior to face particular threat as the priority threat to prevent and to fight, such as: terrorism, radicalism, corruption, money laundry, and much more.

National resilience refer to Pancasila Vision is a function of mental and spiritual resilience, and other additional functions, such as: institutional and political function and also material and technological function Sutowo and Al (2019). Pancasila vision as a function of mental and spiritual resilience is indicated by individual and community resilience while facing social engineering efforts which conducted by the parties from inside or outside Indonesia. The social engineering efforts are the efforts to construct the community construction refer to the party's interest. Institutional and political resilience refer to the vision of Pancasila as the sight in bureaucracy and political activities. Bureaucracy as the governance stakeholder has an important role especially in public service area, to serve the basic need of people and to increase the community life quality. Bureaucracy also has a role to set up public order, generally in public administration. On other hand, political institution or politic party is also an important institution to move forward toward civil society. Democracy needs public participation, and public need the truth. Public see and look forward a rely politic party which utilizing as public aspiration channel. Pancasila vision also the sight in material and technology field. As the sight, material research and technology inventions use Pancasila vision to increase national ability with the aim to get an equal position with other countries.

State defense realization is a right without exception, an obligation and simultaneous as collective responsibility, involving all elements in national life. The effort's essence is the obligation and citizen's responsibility to guard national sovereignty Darmawan (2015). National sovereignty is a national interest, without sovereignty it is impossible to achieve national goal. State defense awareness is important to promote among all citizen. The awareness is promoted as responsibility without pressure from the government, and appear and emerging from each person. Nationalism and patriotism are two important values, and all citizens must be considered as their own values. No country in the world will get the sovereignty without nationalism and patriotism. In the era of pragmatism, nationalism and patriotism reducing and emerging as a national weakness. State defense awareness is promoting in education field, residence field and working field, promoting since the citizen is a child and growing up to be a mature person. State defense is not militarization. It is dissimilar. State defense is about the right and the obligation, the rule which ordered by Indonesia constitution. Reserve component is an exception, civilians are trained with military skills and knowledges, but not to be professional soldier, temporary and limited during the service. But, in reality, the reservist deployment prior to supports the main component if the main component needs to strengthen. The possibility for the reservist to engage in military operation which 
high level of military skills necessary is considered and determined if the situation getting worse and the need to mobilize. The actual and factual threats are indicated that in short and middle term, Indonesia will not be mobilizing the citizens, and the urgency for reserve component establishment is to support national resilience, especially for confronting with nonmilitary threats.

According to Law No, 23/2019, Indonesia government, especially Minister of Defense could be taken with forming and activating the reserve component for anticipating potential threats of a new generation's warfare and construct Pancasila building for the reservists Ryacudu et al. (2021). Pancasila building is a construction which construct the values from Pancasila as the reservist basic and essential values. Establish the reserve component is legal based on Law No. 23/2019 and will increasing both capability and capacity of Indonesia Defense System. Pancasila has two roles, as the vision for reservist and the paradigm for forming and developing reserve component. Pancasila also a structure of norms, a structure which consist of nationalism and patriotism as Pancasila implementations.

The evidence of national resilience is at least evident from the way the Indonesian nation faced communist threats in 1965 and passed the economic and political crisis in 1998, national resilience will continue to face the dynamics of changing times Isabella (2017). Reviewing the history, the dynamics of changing times faced by every country in the world, and national resilience also a universal concept across the nations. Indonesia's experiences evident that national resilience is a dynamic condition and faced with the national crisis. The crisis brought the change in national life, but national resilience is never changing. State defense awareness need to actualize in daily life within communities. The actualization will contribute to national resilience development. Citizen participation as the reservist is one of the state defense awareness actualizations. The reservists on duty temporary, after their service, they will back to their initial professions, but with different identity as the former of reservist who has self-resilience. More and more the citizens take a part in the reserve program, more affection to the communities.

\section{CONCLUSIONS AND RECOMMENDATIONS}

The need to form and develop reserve component is to strengthen Indonesia national resilience with Pancasila Paradigm and Pancasila Vision. Pancasila paradigm useful is to construct the basic values for national component establishment, for national leadership, for national policy makers and decision makers. Pancasila paradigm is determined how national leadership concreting the need in national defense system, including the need to form national reserve component. Pancasila vision is the vision for reservist as national resources and national volunteers. State defense awareness as one of Pancasila implementations must be actualized and reserve component is a program which actualizing state defense awareness. 
The author's recommendation is: Minister of Defense as the defense system leading sector initiating reserve component establishment and focus on delivering Pancasila vision for the reservist. National reserve formed by a synergy step from many stakeholders to strengthen national resilience. National reservist will contribute while nonmilitary threat occurring and impacting the aspects in national life. Finally, the reservists are the citizens who contribute to develop national resilience.

\section{CONFLICT OF INTEREST}

No conflict interest.

\section{ACKNOWLEDGMENT}

None.

\section{REFERENCES}

Bambang, M., \& Pranowo. (2010). Multidimensi Ketahanan Nasional. In Pustaka Alvaber. Jakarta Timur.

Darmawan, C. (2015). Pendidikan Bela Negara Dalam Konteks Keamanan Nasional. Dian Cipta, Bandung.

Endang, Z., \& Sukaya. (2000). Pendidikan Kewarganegaraan. (Hal. 98), PT. Paradigma, Yogyakarta.

Indrawan, R. M. J., \& Efriza. (2018). Building Reserve Components Based On State Defense Capability As Indonesia's Defense Power Facing Non-Military Threats. Journal of Defense \& State Defense, 8(2). http://dx.doi.org/10.33172/jpbh.v8i2.389

Isabella. (2017). Strengthening The National Resilience Of Indonesia Through Socialization Of National Insight. In and others (Ed.), Proceedings of the International Conference on Democracy, Accountability and Governance (ICODAG 2017) (Vol. 163). Retrieved from https://doi.org/10.2991/icodag-17.2017.42

Legal Impact Of State Defense On Indonesian Citizen In International Humanitarian Law Prespective. (2019). In G. A. Bunga \& E. N. B. Tukan (Eds.), Legal Impact Of State Defense On Indonesian Citizen In International Humanitarian Law Prespective (Vol. 8).

Mardhani, D., Runturambi, A. J. S., \& Hanita, M. (2020). Security And Defense In National Resilience Studies To Realize A National Security System. Jurnal Pertahanan \& Bela Negara, 10(3). http://dx.doi.org/10.33172/jpbh.v10i3.1112

Ryacudu, R., , Putra, N., Susilo, A., \& Purwantoro. (2021). The Role Of Reserve Component In Supporting Total People's Defense And Security System (Sishankamrata) To Confront The Threat Of The Sixth Generation Warfare. Jurnal Pertahanan, 7(1), 37-49.

Sutowo, P., \& Al, E. (2019). Membangun Ketahanan Nasional Dengan Paradigma Pancasila, PT. Kompas Media Nusantara. Membangun Ketahanan Nasional Dengan Paradigma Pancasila, PT. Kompas Media Nusantara. 